\title{
CONGENITAL CHAGAS DISEASE OF SECOND GENERATION IN SANTIAGO, CHILE. REPORT OF TWO CASES
}

\author{
Hugo SCHENONE(1), María GAGgERO(2), Jorge SAPUNAR(3), María del C. CONTRERAS(1) \& Antonio ROJAS(1)
}

\begin{abstract}
SUMMARY
Congenital Chagas disease (CChD) has been reported in different countries, mostly in Latin America. In 1987 a fatal case of CChD of second generation (CChDSG) was published. Within a period of six months - 1989-1990 — two cases of CChDSG were diagnosed and studied in the city of Santiago. Two premature newborns, sons of two sisters, with moderate liver and spleen enlargement, were found to have positive serology for Chagas disease and xenodiagnoses. The mothers, urban residents all their lives, without antecedents of triatomine bugs contact or blood transfusions, showed positive serology and xenodiagnoses. Their mother (grandmother of the infants), lived 20 years in a Northern rural Chagas disease endemic locality, in a triatomine infested house. Afterwards, she moved to Santiago, where she married and has resided up to now. Serology and xenodiagnoses were also positive. All the Trypanosoma cruzi infected individuals were successfully treated with nifurtimox.
\end{abstract}

KEYWORDS: Chagas disease; Congenital Chagas disease; Second generation congenital Chagas disease; Congenital infections.

\section{INTRODUCTION}

The possibility of transplacental transmission of Trypanosoma cruzi in humans was raised by Carlos Chagas in $1911^{4}$. Afterwards, numerous authors have studied the problem under diverse approaches: clinical, pathological, parasitological, laboratorial and epidemiological ${ }^{1-3,6-9,11,13,15}$. In 1987 a fatal case of CChDSG was reported in Chile ${ }^{10}$.

In this report we describe two cases of CChDSG, in cousins, ocurred in the city of Santiago.

\section{CASE REPORT}

Patient 1, male, was born in November 1989 in an urban maternity in a Santiago hospital. Body weight at birth was $2,600 \mathrm{~g}$. The patient showed Apgar index 8 and 9 at 1 and $5 \mathrm{~min}$, respectively. Moderate enlargement of liver and spleen were detected. The indirect hemagglutination test (IHAT) for Chagas disease and xenodiagnoses, practiced two weeks later (two out of two boxes containing 7 nymphs III of Triatoma infestans each) gave positive results. The study of the mother - a 20 -year-old healthy woman - provided valuable information: she was born in a Santiago city maternity hospital and had lived in this city her entire life; she did not know triatomine bugs and had not travelled to chagasic endemic areas; she had not received blood transfusions. In spite of these, she presented positive IHAT for Chagas disease and xenodiagnoses (two out of four boxes $=50 \%$ ), tests performed contemporaneously with those of the infant. A remote anamnesis to establish that her mother (grandmother of the patient) - a 51-year-old apparently healthy woman - was born and had lived in Combarbalá (315 $\mathrm{km}$ north from Santiago), a rural village, located in an endemic area of
Chagas disease, in a triatomine bugs infested house, until 1959. Then she moved to Santiago city, where she still resides. The IHAT for Chagas disease and xenodiagnoses (five out of six boxes $=83.3 \%$ ) performed on her resulted positive. In 1987, she presented a megacolon which has been satisfactorily controlled under medical treatment.

Patient 2, male, nephew of the mother of patient 1, was born in April 1990 in a Santiago city maternity hospital. Body weight was 2,750 g. Apgar indexes were normal. Moderate enlargement of liver and spleen were detected. IHAT for Chagas disease and xenodiagnoses (four out of four boxes $=100 \%$ ) performed one week after birth resulted positive. The study of the mother - a 24-year-old healthy woman — gave identical results to those of the mother of patient 1 .

It is interesting to recall that the grandmother married one year after arriving to Santiago (1960) and had five children: three females and two males. The three females, 20, 24 and 27-year-old, presented positive IHAT for Chagas disease and xenodiagnoses, and had had a total of five children: two boys (one is patient 1), one boy (patient 2) and two boys respectively. These five children - two with CChDSG - have been physically and psychologically normal from the age of one month on. The two males - 25 and 28-year-old - presented negative IHAT for Chagas disease and xenodiagnoses.

All these asymptomatic T. cruzi infected individuals, patients 1 and 2, their mothers and the third mother who had two non infected children, were successfully treated with nifurtimox, and repeatedly, during three years, had had negative xenodiagnoses. The IHAT for Chagas disease of the two infected children became also negative later on.

(1) Programa de Parasitología, ICBM, Facultad de Medicina, Universidad de Chile, Santiago, Chile.

(2) Servicio de Neonatología, Hospital San José, Santiago, Chile.

(3) Departamento de Medicina, Hospital Clínico de la Universidad de Chile, Santiago, Chile.

Correspondence to: Dr. Hugo Schenone, Programa de Parasitología, ICBM, Facultad de Medicina, Universidad de Chile. Casilla 9183. Santiago, Chile. 


\section{COMMENTS}

A fundamental factor arises in these case reports: the transplacentary transmission of $T$. cruzi to the fetus. This situation may occur anywhere in the world when an infected woman - asymptomatic in most of the cases - becomes pregnant and gives birth to an infected newborn. This phenomenom appears in $0.3-10.7 \%$ of cases $^{2,11,14,15}$. The case of CChD in a boy who was born in Romania in 1975 by a Latin American infected mother is well known?

$\mathrm{CChD}$ can originate diverse degrees of organic involvement, from slight and transient symptoms and signs to severe and mortal damage $\mathrm{e}^{7,8}$. On the other side, an important proportion of $\mathrm{CChD}$ is asymptomatic ${ }^{11}$. This later situation corresponds to the three cases of $\mathrm{CChD}$ in the mothers and the two cases of CChDSG in the boys here reported.

In considering retrospectively this peculiar long term familiar $\mathrm{CChD}$, it is possible to verify that the clinical-epidemiological history began with the infection of the grandmother, quite likely infected by the vector, and followed by the three daughters (CChD) and two grandsons (CChDSG).

CChD habitually appears in Chagas disease endemic areas, countries or regions ${ }^{8}$, however it can by seen in localities, countries or continents where neither vectors nor authoctonous $T$. cruzi infected individuals have ever existed ${ }^{9}$.

According to our available facilities, in the present study xenodiagnosis has been preferred among other etiological techniques because its feasibility, reproductivity an reasonable easy and uniform management, both for acute (congenital in this particular situation) and chronic T. cruzi infections ${ }^{12}$.

It is possible that all these familiar infections, besides the susceptibility of the affected individuals, may be the consequence of a very virulent strain of the parasite - though not necessarily very pathogenic - which produced the high parasitemias detected by means of xenodiagnosis positive boxes: $83.3 \%$ in the grandmother, 50 and $50 \%$ in the daughters, and $100 \%$ in the grandsons ${ }^{12}$.

In summary, the possible diagnosis of CChDSG must be taken in consideration not only in Chagas disease endemic areas, but also in children born in non endemic areas whose mothers or grandmothers proceed from these areas.

\section{RESUMEN}

\section{Enfermedad de Chagas congénita de segunda generación en Santiago, Chile. Relato de dos casos}

La enfermedad de Chagas congénita ha sido reportada en diferentes países, en su gran mayoría de Latinoamérica. En 1987 un caso fatal de enfermedad de Chagas congénita de segunda generación fue publicado. En 1989-1990 dos casos de enfermedad de Chagas congénita de segunda generación fueron diagnosticados y estudiados en la ciudad de Santiago. Dos recién nacidos prematuros, hijos de dos hermanas, con moderado aumento del hígado y del bazo, presentaron serología para enfermedad de Chagas y xenodiagnósticos positivos. Las madres, residentes urbanas toda su vida, sin antecedentes de contacto con triatominos ni transfusiones de sangre presentaron serología y xenodiagnósticos positivos. La madre de ellas (abuela de los niños) nació y vivió 20 años en una localidad rural de endemia chagásica, en una casa infestada con triatominos. Posteriormente, se trasladó a vivir a Santiago, donde se casó y ha residido hasta el presente; su serología y xenodiagnóstico fueron positivos. Todas las personas infectadas con Trypanosoma cruzi fueron tratadas exitosamente con nifurtimox.

\section{REFERENCES}

1. ASTORGA. B.; THIERMANN, E.; LORCA. M. et al. - Estudio sobre la enfermedad de Chagas congénita en zonas endémicas. Bol. Hosp. San Juan de Dios, 29: 259-264, 1982.

2. AZOGUE, E. \& DARRAS, C. - Chagas congénito en Bolivia: estudio comparativo de la eficacia y el costo de los métodos de diagnóstico. Rev. Soc. bras. Med. trop., 28: $39-43,1995$

3. BITTENCOURT, A.L. - Possible risk factors for vertical transmission of Chagas disease. Rev. Inst. Med. trop. S. Paulo, 34: 403-408, 1992.

4. CHAGAS, C. - Molestia de Carlos Chagas. Segunda conferencia realizada na Academia Nacional de Medicina em Agosto de 1911. In: CHAGAS, C. Coletânea de trabalhos científicos. Brasilia, Editora Universidade de Brasilia, 1981. p. 167-191. (Coleção Temas Brasileiros, v. 6).

5. DAO, L. - Otros casos de enfermedad de Chagas en el estado de Guarico (Venezuela). Formas agudas y crónicas. Observación sobre enfermedad de Chagas congénita. Rev. Policlín. Caracas, 18: 17-22, 1949.

6. FRANCA-RODRIGUEZ, M.E; SALVATELLA, R.; CERUZZI-ROMEO, O. et al. - Los 4 primeros casos de infección chagásica congénita diagnosticados retrospectivamente en Uruguay. In: CONGRESSO DA SOCIEDADE BRASILEIRA DE MEDICINA TROPICAL, 20. E CONGRESSO DA SOCIEDADE LATINOAMERICANA DE MEDICINA TROPICAL, 1., Salvador, 1984. p. 154.

7. HOWARD, J. \& RUBIO, M. - Congenital Chagas' disease. I. Clinical and epidemiological study of thirty cases. Bol. chil. Parasit., 23: 107-112, 1968.

8. LOPES, E.R.; CHAPADEIRO, E.; CUNHA, M.B.R. \& FONSECA, M.A. - Doença de Chagas congênita no Triângulo Mineiro. Relato de um caso. Rev. Inst. Med. trop. S. Paulo, 19: 165-169, 1977.

9. PEHRSON, P.O.; WAHLGREN, M. \& BENGTSSON, E. - Asymptomatic congenital Chagas' disease in a 5-year-old child. Scand. J. infect. Dis., 13: 307-308, 1981.

10. SCHENONE, H.; IGLESIAS, J.; SCHENONE, S. \& CONTRERAS, M.C. - Infección chagásica congénita de segunda generación. Bol. chil. Parasit., 42: 71-73, 1987.

11. SCHENONE, H.; CONTRERAS, M.C.; BORGOÑO, J.M. et al. - Algunas características epidemiologicas, clínicas y parasitológicas de la enfermedad de Chagas congénita en Chile. Rev. Pediat. (Santiago), 32: 65-72, 1989.

12. SCHENONE, H. \& ROJAS, A. - Estudio longitudinal, mediante el xenodiagnóstico, de la parasitemia en pacientes con infección por Trypanosoma cruzi crónica. Bol. chil. Parasit., 54: 29-32, 1999

13. SCHMUÑIS, G.A. \& SZARFMAN, A. - La enfermedad de Chagas congénita. Medicina (B. Aires), 37: 47-53, 1977

14. VALPERGA, S.M.; CASTAGNARO, A.E.; OVEJERO, G.J. et al. - Prevalencia de Chagas congénito: segundo estudio en Tucumán, Argentina. Cienc. méd. (San Miguel de Tucumán), 7: 137-155, 1992.

15. ZAIDENBERG, M. \& SEGOVIA, A. - Enfermedad de Chagas congénita en la ciudad de Salta, Argentina. Rev. Inst. Med. trop. S. Paulo, 35: 35-43, 1993.

Received: 24 January 2001

Accepted: 26 March 2001 